\title{
Organizational Culture Analysis of Khyber Pakhtunkhwa's Higher Educational Institutions, A Knowledge Culture Perspective
}

\author{
SHABANA GUL \\ Assistant Professor, Institute of Management Sciences, Peshawar \\ Email: shabana.gul@imsciences.edu.pk \\ WASEEF JAMAL \\ Associate Professor, Institute of Management Sciences, Peshawar \\ Email: waseef.jamal@imsciences.edu.pk
}

\begin{abstract}
This article offers an analysis of the prevailing organizational cultures of KP-HEI and their comparison with that of knowledge-based cultures. Primary data from 555 faculty members from 10 public sector KPHEIs was collected. Two-layer stratified random sampling was used to reach the unit of observation. Organizational culture assessment instrument (OCAI) developed by Cameron and Quinn (1999) was used for collecting data on the organizational culture of sampled HEI. The unit of observation was the faculty members of sampled HEI whereas the unit of analysis was the respective HEI. The output of the study was 10 organizational culture profiles of KP-HEI, outlining the organizational culture types, orientations, and dominant characteristics of each of the sampled KP-HEI. The majority of KP-HEI were found to have clan culture as a dominant organizational culture type, with an internal focus in strategic emphasis.
\end{abstract}

Keywords: Organizational Culture, Knowledge based cultures, Higher Education Institutions, Organizational Culture Profiles.

\section{Introduction}

Higher education institutions (HEIs) are organizations with complex and dynamic structures, characterized by their multi-product nature. This feature, through which HEIs produce teaching and research across various subjects and different levels make an evaluation of their performance very difficult, since an HEI that performs well in one dimension may fare far worse in another (Agasisti, \& Johnes, 2015). Higher education institutions are globally recognized to play a critical role in the progression of knowledge economies (Ponnuswamy \& Manohar, 2014). In past decade numerous innovations have been introduced in higher education, such as the creation of international cooperation networks, increase in academic mobility of faculty and students, new management structures, new assessment methods, accreditation, diversification in the programs, courses and studies, and the utilization of technology in teaching and learning (Zhu \& Engels, 2014). Hence due to the complexity and diversity of these relations, it is absolutely necessary to study the organizational culture (OC) of HEIs as OC is considered as a fundamental and important component in an organization (Zamini, Zamini, \& Barzegary, 2011). In the last decade, organizational culture has emerged as a topic of great importance (Taye, Sang \& Muthanna, 2019), as the study of organizational culture is critical for the organization to implement its strategies (Bashir, Jianqiao, Abrar, \& Ghazanfar, 2012). Organizational culture is, most often, the component that moves the organization forward. OC creates an environment in which every individual aim to achieve goals established by the 
organization (Tănase, 2015). According to Antić and Cerić (2008), it is virtually impossible to evaluate a modern organization without studying its organizational culture. However, culture is a highly complex and dynamic construct with various authors defining 'culture' differently. Consequently, organizational culture faces numerous challenges and is very difficult to define (Antić \& Cerić, 2008).

Understanding an organization's culture is important for the stakeholders, the employees, as well as the organization in general. Culture shapes the organization's effective decision making; appropriate behavior for the employees; and the attitude of external stakeholders towards the organization Desson and Clouthier (2010). Moreover, understanding the organizational culture will support the administrators in identifying and resolving conflicts and manage change efficiently and effectively.

Higher Education Institutions (HEI) of Pakistan are operating in a highly dynamic environment and are exposed to challenges that have accrued because of structural changes in managing higher education in the country. Some critical reforms made in the sector since 2002 include the evolution of the Higher education commission (HEC). Higher Education Commission of Pakistan aims to develop HEI as leading and enabling centers for transformation into a knowledge economy via innovation and entrepreneurship (based on Govt. of Pakistan vision 2025). Thus, evaluation of current organizational cultures of HEI for understanding the prospective role of HEI cultures in the envisioned cultures is essential, however, no data is available on the type of organizational cultures of HEI, the organizational cultural orientation of HEI, and the dominant characteristics of organizational culture that are essential for supporting a knowledgebased culture. A knowledge culture is a culture that supports knowledge creation, transfer, utilization and implementation. The study proposed to fill the gap by conducting a comprehensive study to develop organizational culture profiles of KP-HEIs. The organizational culture profiles of HEI explore the organizational culture type, orientation, focus, and dominant organizational culture characteristics. Furthermore, the study also attempts to compare and contrast the organizational culture profiles of sampled HEI with that of knowledge cultures.

\section{Mission of Higher Education Institutions (HEI)}

For understanding the organization culture of HEI, it is important to understand the mission of HEI i-e why do they exist? Many authors agree that HEI exists for the creation, transformation and transfer of knowledge (Pineda, Zapata \& Ramirez, 2010). This has been the primary mission for almost all the HEI regardless of their geographical and technical operations. Educationists consider HEI as teaching, at the same time research institutions, where knowledge is the main input and output component (Tippins, 2003). Le Feuvre \& Mesto's (2005) supported the same view by considering university as a whole with teaching and research as two subsystems, the former for the dissemination of knowledge and the latter focusing on creating new knowledge. However, the mission of HEI is highly influenced by national culture, government policies on education, government funding for research, globalization and stakeholders' priorities (faculty, administration, students and industry). Le Feuvre and Mesto (2005) developed three academic models of HEI on the basis of national culture and government policy on education. The Humboldt Model focuses on integrating teaching and research in multi-disciplines. The universities enjoy autonomy regardless of being exclusively financed by the state. The faculty is autonomous in the selection of research areas and methodology and also in developing subject content and methods of teaching. In Napoleonic Model the state controls universities, where teaching and research are considered separate activities. In this model, research activity is driven by public sector priorities, who are involved in different thematic areas of research. University academics are mono-discipline and are controlled by the state as a system from curriculum development to finances. Whereas, in the Anglo-American Model universities carry out both teaching and research but the content of both is rooted in the needs of the society rather than the research interest of academics (as in Humboldt Model) or policy objective of the government (as in Napoleonic Model). 
According to Le Feuvre and Mesto's (2005) report, the aforementioned HEI models have a certain embedded weakness that may prevent HEI to compete in the knowledge economy. The HEI following the Humboldt model may not meet the stakeholders' requirements or interests. Similarly, HEIs in Napoleonic are too dependent on state priorities whereas the Anglo-American Model is solely driven by society.

Service University was termed in 1986, by Canadian research administrators (Enros \& Farley, 1986). Given the budget constraints, the universities increased their knowledge production more effectively and efficiently by selling their knowledge products to external stakeholders either in research, teaching, or consultancies. Tjeldvoll (2002) and Cummings (1995) compared and contrasted, the traditional "Research Universities" with "Service Universities". The following table summarizes the comparison between research universities and service universities.

Table-1 Comparison of Traditional Research Universities VS. Service Universities

\begin{tabular}{|llll|l|}
\hline & Traditional Research Universities & Service Universities \\
\hline Context & $\begin{array}{l}\text { Napoleonic Model: production of } \\
\text { knowledge is driven by academic } \\
\text { interests }\end{array}$ & $\begin{array}{l}\text { Knowledge production is application- } \\
\text { driven as per the interest of stakeholders. }\end{array}$ \\
\hline Discipline & $\begin{array}{l}\text { Humanities and science (based on } \\
\text { disciplines) }\end{array}$ & $\begin{array}{l}\text { Professional schools (knowledge is } \\
\text { cross/trans-disciplinary). }\end{array}$ \\
\hline Courses & Under-graduate and post-graduate & $\begin{array}{l}\text { Post-baccalaureate degrees and training } \\
\text { programs designed for clients }\end{array}$ \\
\hline Duration & Year-long courses & Less than a year courses \\
\hline $\begin{array}{l}\text { Knowledge } \\
\text { production } \\
\text { location }\end{array}$ & $\begin{array}{l}\text { Homogeneous i-e in a fixed or } \\
\text { permanent structure } \\
\text { department or institute }\end{array}$ & $\begin{array}{l}\text { Heterogeneous i-e project organization, } \\
\text { ahen the project is finished the structure } \\
\text { disappears. }\end{array}$ \\
\hline Employment & $\begin{array}{l}\text { Lifetime } \\
\text { Structure }\end{array}$ & $\begin{array}{l}\text { Research organization layered on } \\
\text { top of the teaching organization } \\
\text { Decentralized choice of research }\end{array}$ & $\begin{array}{l}\text { Service is carried out in parallel units } \\
\text { Central planning and contracting of } \\
\text { service. }\end{array}$ \\
\hline Funding & State-funded & Funding by contracts (clients) \\
\hline Quality Control & Peer review & $\begin{array}{l}\text { Reflexive quality control through } \\
\text { stakeholders }\end{array}$ \\
\hline
\end{tabular}

Adapted from Tjeldvoll (2002) and Cummings (1995)

The pressure of globalization pushed universities to be more market-oriented and innovative in their conduct (Tjeldvoll, 2002). Thus, the term Entrepreneurial Universities was marketed by Clark (1998). According to Clark (1998), entrepreneurial universities are like market-based companies, whose survival is based on market responsiveness and adaptability. Globalization pressure also leads to the creation of Virtual Universities and Net Universities (Weber, 1996). There are different degrees of being virtual or netbased universities. Some of them do not have any physical structure and are purely net-based, others have virtualized some part of their activities.

Paul (1990), identified four operational models related to higher education institutions (an operational model is a way an organization operates across a range of domains to accomplish its functions and goals (Paul, 1990)). Bureaucratic model is a well-established hierarchy (from vice-chancellor to faculty and administration) governed by set rules and regulations (Dill, 1992; Smart \& John, 1996). Collegiate model is a collection of specialized professionals taking a decision based on mutual consensus to protect individual 
professional autonomy. In Political model power groups are recognized and their interests are protected in decision making (Mintzberg, 1983). Whereas, in Anarchic model the institution is like an organized anarchy, with vague vision, unclear goals, fluid participation and elusive technology.

\section{Organizational Culture of HEI}

Organizational culture is a widely studied concept in HEI as it relates to the perception of HEI governance rooted in the values and beliefs of HEI stakeholders (Clark, 1998; Masland, 1985). The mission of the universities determines their organizational culture, as university culture is nothing more than the sum of the values and beliefs of university stakeholders that includes administrators, faculty, students, board members, and support staff (Bartell, 2003). Though this definition clearly appears to be a more traditional and holistic view of HEI, as it does not take into consideration the type of university (aforementioned models) and new emerging stakeholders e.g. industry, government, donor bodies and community, yet it can be inferred that organization culture of HEI is the aggregation of values and beliefs of various stakeholders. Though the literature has identified different models of a university given the changing market dynamics, however little is available on the type of culture required for each model. In the context of the operational models of HEI, Davies (1996) and McNay (1995) recognized four HEI cultures. In Corporate Culture: senior management leads the institution with top-down planning and monitors performance via key performance indicators. Policies are tightly defined and implemented. In Bureaucratic/Hierarchy Culture has internal emphasis with the dominance of administration and committees, stability is the strategic goal and leadership style is that of coordinator or organizer where parts (faculty, administration, and students) are bonded together via loosely defined but tightly implemented policies (Cameron \& Quinn, 1999). In an Enterprise Culture individuals interact freely with the external environment with a strong quality framework. Policies are tightly defined but loosely implemented. Whereas the Collegial Culture provides individual autonomy, devolution of authority leading to the dominance of academic committees, freedom of expression, polices are loosely defined and implemented.

Sporn (1996) divided HEI cultures as weak or strong culture with internal or external focus. Weak culture have loosely linked parts (faculty, administration), with their own style of functioning whereas strong cultures have high level of conformity regarding values, goals, and approaches. In Internal focus, individuals are more concerned about their own work rather than the university as a whole. In external orientation, awareness and responsiveness towards the external environment are prioritized.

Mintzberg (1983), considered HEI as professional bureaucracies, where a clear division of labor tasks, e.g. different departments in case of HEI, clarity in authority and responsibility e.g. tenured professors, lecturers and research assistants, etc., and emphasis on formal expertise e.g. full professor, associate professor and assistant professor etc., can be observed. Weick (1976), however, considered HEI culture as a loosely coupled system, there is a connection between the parts (through strategy) but at the same time, each part has its own independent existing i-e programs, departments.

\section{Knowledge-Based Organizational Cultures}

Knowledge-centered cultures are known to support the transfer of knowledge (Peralta \& Saldanha, 2014), several studies have identified the characteristics of knowledge-based cultures or knowledge-centered cultures (e.g. De Long, 1997; Wiig, 1997; Davenport \& Prusak, 1998; Cohen, 1998; Pfeffer \& Sutton, 2000; Alavi \& Leidner, 2001; Janz \& Prasarnphanich, 2003; Smith \& Mckeen, 2003). Based on the mentioned studies, this sections summarize the characteristics of knowledge-based organizational cultures and develops a criterion (based on the mentioned studies) that will assist in comparing the organizational cultures of KP-HEI (sample of the study) with that of knowledge-based cultures.

De Long (1997) considered the importance of knowledge in an organization and the norms and values attributed to the use of internal and external knowledge as the most important characteristic of a 
knowledge-based culture. Organizations that consider the knowledge and learning important and value the use of knowledge at the workplace are considered as knowledge-based cultures. De Long (1997) was of the opinion that sub-cultures within the organization conceives or deals knowledge differently, few consider it as an object to be used as a part of a process, others recognize and favor knowledge as a product of social interaction. The author stated that organizational cultures not only define and value knowledge but also decides what kind of knowledge should be kept inside the organization for creating core competencies and what should be transferred outside the organization for strategic advantages. Similarly, De Long advocated that its culture that decides the distribution of knowledge within and among organizations.

Wiig (1997) described four areas that are focused on knowledge-based cultures. Firstly, such cultures have a top-down monitoring governance strategy for managing knowledge management activities that include incentives for knowledge sharing, identification of knowledge assets, restructuring plans (if required). Secondly, knowledge-based cultures have a knowledge-based staff development strategy focusing on the creation and maintenance of knowledge infrastructure. The strategy includes lessons learned programs, development of professional resource pool and implementation of knowledge base plans. Thirdly, such cultures have an operational knowledge management strategy that focuses on managerial responsibilities, training and development plans, research and development, acquisition, innovation and transformation of knowledge. Lastly, knowledge-based cultures have knowledge leverage strategies that focus on the introduction of best practices for knowledge management, a collaboration that yields productive use of knowledge assets.

Contrary to Wiig (1997), Bollinger and Smith (2001), were of the opinion that instead of management focus, knowledge management activities should be an HR function i-e. initiated and implemented by the human resource department. The authors supported the meaningful role of the HR department in knowledge-based cultures. Bollinger and Smith (2001) supported the reward and compensation systems based on knowledge sharing and nurture. They suggested that training and development should be led by the sole aim of educating employees about the use of knowledge. In knowledge-based cultures, line supervisors are trained and empowered to promote knowledge sharing. Jobs are designed as teams with administrative autonomy, to take advantage of individual know-how. The leadership of knowledge-based cultures values knowledge sharing, retaining people, loyalty and commitment towards the organization.

Davenport and Prusak (1998) supported the idea of reward management systems based on knowledge sharing, encouragement of risk-taking and innovative ideas implementation in knowledge-based cultures. Cohen (1998) supported Nonaka and Takeuchi (1995) and advocated socialization and interaction opportunities provisions as a pre-requisite for knowledge sharing in knowledge-based cultures. The authors supported face-to-face relationships, cooperative and collaborative interactions among individuals.

Pfeffer and Sutton (2000) were of the opinion that there is a gap between what people know and what people do in an organization, therefore the focus of knowledge-based cultures should be on the actual ability of individuals to turn knowledge into effective action. Alavi and Leidner (2001) supported the same theme and advocated that there may be occasions where organizational members are not only knowledgeable but are also willing to share knowledge yet, they do not act upon it or materialize the intention of sharing. Thus, the actual conversation of knowledge into action and knowledge sharing activities should be included in incentivizing knowledge-based activities.

Aligned with the mentioned literature, Janz and Prasarnphanich (2003) also supported an organizational culture based on risk-taking, support, warmth and rewards, collaborative learnings focusing on positive interdependence, promotive interactions and group processes, autonomy related to people, planning and process as characteristics of knowledge-based cultures.

Smith and Mckeen (2003) identified four categories of factors i-e. Social, organizational, managerial, and technical that assist in instilling a knowledge-based culture. The socialization category focuses on 
orientation and socialization of new employees, job rotation policies, team-based structures and provision of an interactive, informal environment in an organization. The organizational category focuses on incentives and rewards, governance and accountability structures, the flow of information and tracking and integration of knowledge resources. Whereas, managerial factors include continuous communication about the use and importance of knowledge by leaders and management that is shown via training programs, job designs and incentives and rewards strategies. Lastly, the technical category includes the introduction of well-designed, user-friendly technological interventions that complements the social, organizational and managerial categories mentioned before. Knowledge-based cultures are summarized as follows:

Table-2 Characteristics of Knowledge-Based Cultures

\begin{tabular}{|c|c|c|}
\hline $\begin{array}{l}\text { Intervention } \\
\text { Level }\end{array}$ & $\begin{array}{l}\text { Knowledge-Based Strategies and } \\
\text { Activities }\end{array}$ & Source \\
\hline \multirow{5}{*}{$\begin{array}{l}\text { Organizational } \\
\text { Level }\end{array}$} & $\begin{array}{lll}\text { Risk-taking and innovative } & \text { ideas } \\
\text { supportive leadership } & & \\
\end{array}$ & \multirow{5}{*}{$\begin{array}{l}\text { - Wiig (1997) } \\
\text { - Smith and Mckeen (2003) }\end{array}$} \\
\hline & $\begin{array}{l}\text { Top-down knowledge monitoring and } \\
\text { governance strategy }\end{array}$ & \\
\hline & $\begin{array}{l}\text { Knowledge leverage strategy based on } \\
\text { collaboration and cooperation (within and } \\
\text { outside the organization) }\end{array}$ & \\
\hline & $\begin{array}{l}\text { Reward and Incentives Strategy based on } \\
\text { knowledge sharing and new knowledge } \\
\text { product and processes development }\end{array}$ & \\
\hline & $\begin{array}{l}\text { A well-designed and a user-friendly central } \\
\text { database for knowledge tracking and } \\
\text { integration }\end{array}$ & \\
\hline \multirow{4}{*}{$\begin{array}{l}\text { Managerial } \\
\text { Level }\end{array}$} & $\begin{array}{l}\text { Knowledge management based orientation } \\
\text { and socialization policy }\end{array}$ & \multirow{4}{*}{$\begin{array}{l}\text { - Wiig (1997) } \\
\text { - Davenport and Prusak (1998) } \\
\text { - Pfeffer and Sutton (2000) } \\
\text { - Bollinger and Smith (2001) } \\
\text { - Alavi and Leidner (2001) } \\
\text { - Janz and Prasarnphanich } \\
\text { (2003) } \\
\text { - Smith and Mckeen (2003) }\end{array}$} \\
\hline & Autonomous team-based job designs & \\
\hline & $\begin{array}{l}\text { Knowledge-based staff development } \\
\text { policy }\end{array}$ & \\
\hline & $\begin{array}{lll}\begin{array}{l}\text { Promotive } \\
\text { provisions }\end{array} & \text { interaction } & \text { opportunities } \\
\end{array}$ & \\
\hline
\end{tabular}

\section{Organizational Culture Challenges of HEI in Transfer of Knowledge}

Knowledge transfer in HEI is not a new concept as HEI exists to create and disseminate knowledge, what's new is the institutionalization of university-industry linkage (Reichenfeld, 2011). Wedgewood (2006) called this new reality as "mainstreaming the third stream", which demands significant engagement from academics. Wedgewood (2006) argued that universities cannot survive on the basis of teaching and research, they have to collaborate with the third sector for creating meaningful social and economic impact. HEI should transfer knowledge not only for creating income by generating patents and licenses but also for developing meaningful academic collaborations with non-profit organizations, government and other organizations for developing strategically efficient improvements in partner organizations (Reichenfeld, 2011). The shift from an industrial economy to a knowledge economy has undoubtedly put HEI under pressure; with governments demanding more usable knowledge with cost efficiency, industry demanding ready knowledge products rooted in innovation and internationalization of HEI demanding more marketlinked curriculum (Levine, 2006).

Tippins (2003) argued that the bureaucratic culture of HEI creates a number of challenges for transfer of knowledge, e.g. for faculty knowledge is a personal property rather than an asset with value, 
similarly, the faculty is confined to universities and seldom interact with the external environment thus the creation of social networks for the successful transfer of knowledge is hindered. Tippins (2003), further advocates that variation in understanding of knowledge among faculty members and their negative aspects of expert status and competition along with the use of impersonal communication makes a transfer of knowledge more challenging.

Knowledge is not freely shared among faculty members and in the process valuable knowledge is lost and not only this but even if the knowledge is transferred it is not enriched by different perspectives and fields of study and thus the standard of created knowledge is affected (Wigg, 1993). Rowley (2000), pointed out that the transfer of knowledge is dependent on individuals along with other factors. He further elaborated that individual recognition as a person of repute based on his/her personal knowledge base, research output and publication in HEI creates opportunities for transfer of knowledge. But the lack of strategic alliance among HEI at the international level and global knowledge repositories represent a challenge for HEI in the creation of a knowledge environment (Rowley, 2000).

The Council for Industry and Higher Education, UK studied 22 business firms to understand the role of university research (knowledge transfer) in innovation (Docherty et al., 2010). They identified a set of factors that influenced the knowledge transfer relationship between university and industry: lack of crossdiscipline, communication and interaction between faculty caused problems for firms (as firms had to approach different sources for business solutions), for business solutions), university researchers focused more on replication and vigorous results as research outputs, whereas firms could only manage $80 \%$ of solutions, lack of shared expectation between university and firms resulted in trust deficit, the time taken by universities to process the need of firms pressured the firms, especially those firms with shorter innovation cycles and finally the role of technology transfer offices created hindrance in the process rather than facilitation.

Winter (2009) identified the customization of knowledge products (needed by the industry and provided by the HEI) as a challenge in the industry-academia knowledge transfer process. According to Winter (2009), academia needs to produce knowledge in the language of the industry so that it is easy for the industry to decode and use, and for academia to attract industry with such knowledge products.

Reichenfeld (2011), pointed out that social scientists are less inclined to transfer knowledge as they consider the transfer of knowledge, in terms of its output, e.g. spins outs, patents and licensing etc., something related to engineers and scientists. He further elaborates that the commercialization of research as a means for transfer of knowledge has created a bias in HEI and has created a drift from the intellectual and scholarly value of more profit-orientation. Irwin \& More (1991) identified seven different barriers in the transfer of knowledge between HEI and industry: i) use of expert academic jargons in knowledge products by academia, ii) prevailing reward systems in HEI, iii) divergence in motivation; faculty interested in publication vs secrecy request by industry in collaborative research, iv) difference in the organizational culture of HEI and industry, v) procedural differences in applying for licensing and contracts in HEI and industry, vi) lack of technical knowhow for using technology and vii) lack of financial resources for R\&D related to transfer of knowledge technology.

European Commission's report on improving knowledge transfer between research institutions and industry across Europe (2007) has identified several key issues in the transfer of knowledge from HEI to industry, e.g. cultural differences in academia and industry, legal barriers, market fragmentation and lack of reward and incentive strategy for the transfer of knowledge. The report further elaborates that the autonomy of organizations (HEI and industry) in hiring appropriate staff for transfer of knowledge has been yet another challenge Though increase mobility between public and private sector can resolve the issue rules related to not allowing public sector researcher to work on part-time or consultancy basis for the industry can be challenging for such resolutions. 
Bruneel et al., (2009 a) were of the opinion (based on their research) that UK based universities are going in the wrong direction in their university-industry engagement programs. They cited two major reasons for this drift; $65 \%$ of the surveyed barriers were attributed to the long term nature of university's research whereas $55 \%$ was attributed to the rules related to confidentiality and IP related issues. These findings reflect an interesting insight into the transfer of knowledge from university to industry. In their later study $(2009$ b) they termed these barriers as "orientation barriers" and "transaction barriers". Orientation barriers were rooted in university research biasness towards pure sciences, long term nature of knowledge-based research and lack of mutual work understanding and expectations. Whereas, transaction barriers included: unrealistic expectations, conflicts related to intellectual property rights and confidentiality, and rules and policies of funding bodies.

Ternouth, et al., (2012) conducted a study assisted by the Technology Strategy Board and the Research Councils that resulted in 5C's model. The model explained the knowledge transfer process between universities and companies. The model also identified embedded barriers at each stage. The model's first stage is the company's ability to locate and recognize an opportunity (C1) whereby a partner university can assist them in finding a solution through their (university's) knowledge product. Once the opportunity is located, issues of co-recognition (C2) arise, given the settlement of co-recognition issues, the barriers to coformulate (C3) a knowledge solution stems up between the Partner University and company followed by co-creation (C4) and commercialization (C5).

The following table provides a summary of challenges embedded in organization culture that directly influences the transfer of knowledge process in HEI

Table-3 Organizational Cultural Barriers in Transfer of knowledge (HEI Context)

\begin{tabular}{|c|c|}
\hline $\begin{array}{l}\text { HEI Cultural } \\
\text { Barriers }\end{array}$ & Description \\
\hline $\begin{array}{l}\text { Faculty Behavior } \\
\text { Barriers }\end{array}$ & 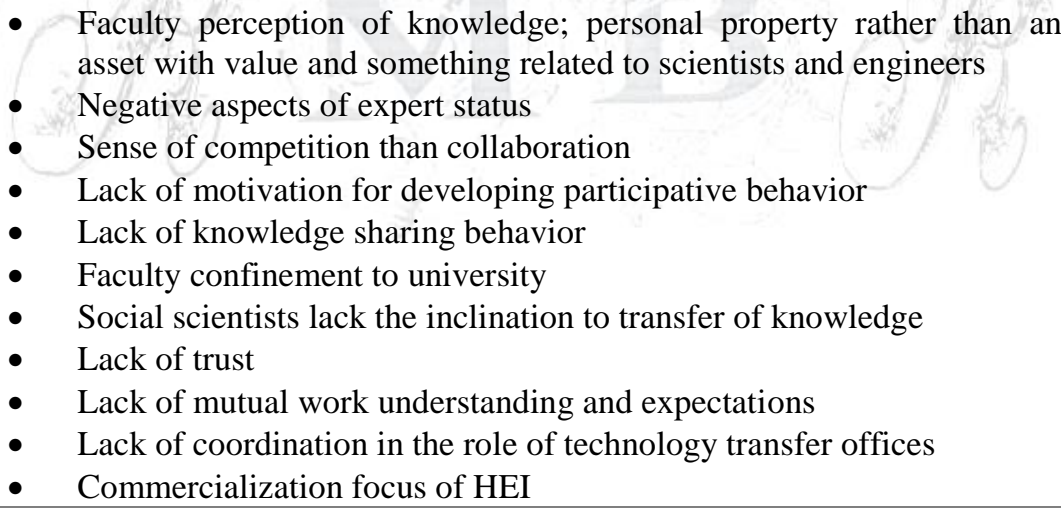 \\
\hline $\begin{array}{l}\text { Faculty Capacity } \\
\text { Barriers }\end{array}$ & $\begin{array}{l}\text { - Transfer of knowledge is dependent on individuals (faculty) of repute } \\
\text { based on his/her personal knowledge base, research output, and } \\
\text { publication } \\
\text { - } \quad \text { Variation in faculty knowledge absorption capacity } \\
\text { - } \quad \text { HEI research biasness towards pure sciences }\end{array}$ \\
\hline $\begin{array}{l}\text { Expectation } \\
\text { Barriers }\end{array}$ & $\begin{array}{ll}\text { - } & \text { Goal/objective dissimilarity between HEI and Industry } \\
\text { - } & \text { Lack of shared expectation between HEI and industry } \\
\text { - } & \text { Unrealistic expectations }\end{array}$ \\
\hline Content Barriers & $\begin{array}{l}\text { - Use of expert academic jargons in knowledge products by academia } \\
\text { - } \quad \text { Lack of global knowledge repositories }\end{array}$ \\
\hline $\begin{array}{l}\text { Information } \\
\text { systems Barriers }\end{array}$ & $\begin{array}{l}\text { - } \quad \text { Lack of strategic alliance among HEI at the international level } \\
\text { - } \quad \text { Lack of cross-discipline communication and interaction }\end{array}$ \\
\hline
\end{tabular}




\begin{tabular}{|c|c|}
\hline & $\begin{array}{l}\text { - Use of impersonal communication by faculty } \\
\text { - } \quad \text { Lack of interaction opportunities }\end{array}$ \\
\hline $\begin{array}{l}\text { Procedural } \\
\text { Barriers }\end{array}$ & $\begin{array}{ll}\text { - } & \text { Procedural differences in applying for licensing and contracts in HEI } \\
\text { - } & \text { and industry } \\
\text { - } & \text { HEI rules and regulations } \\
\text { - } & \text { Rules and policies of funding bodies } \\
\text { - } & \text { Lack of strategic alliance among HEI at the international level } \\
\text { - } & \text { Lack of appropriate reward systems in HEI } \\
\text { - } & \text { Time-consuming procedural issues in HEI } \\
\text { - } & \text { Organizational autonomy of HEI in hiring appropriate staff }\end{array}$ \\
\hline
\end{tabular}

Transfer of knowledge processes or activities generally fails because organizations adapt their culture to knowledge transference activities rather than to implement them as per their organization culture. The literature argues that organizational culture type that facilitates transfer or sharing behavior, in general, will affect the transfer behavior of faculty directly i-e in terms of supportive strategy, leadership characteristics and strategic emphasis etc. Thus barriers in organizational culture are essentially the depiction of the prevailing type of organizational culture.

\section{Methodology}

\section{Population and Sampling}

KP-HEI with the following characteristics (population parameters) were shortlisted as the population of the study:

i. Public sector universities/Degree Awarding Institutions recognized by HEC operating in Khyber Pakhtunkhwa (KP before FATA merger), with at least one humanities department.

ii. The Public Sector University established in or before 2012.

As per the aforementioned population parameters, $17 \mathrm{HEIs}$ in KP were selected as the total population. Once the total population was determined, the stratified random sampling technique was applied. Random samples were drawn per HEI. The sample size for each HEI is as follows:

Table-4 List of Population and Sample

\begin{tabular}{|l|l|l|l|l|l|l|l|l|l|l|l|l|l|l|l|l|l|}
\hline HEI & 1 & 2 & 3 & 4 & 5 & 6 & 7 & 8 & 9 & 10 & 11 & 12 & 13 & 14 & 15 & 16 & 17 \\
\hline $\begin{array}{l}\text { Population } \\
\text { (faculty) }\end{array}$ & 387 & 115 & 163 & 275 & 102 & 233 & 334 & 177 & 130 & 169 & 315 & 115 & 226 & 402 & 119 & 122 & 61 \\
\hline Sample & 194 & 89 & 115 & 161 & 81 & 146 & 179 & 122 & 98 & 118 & 174 & 89 & 143 & 197 & 92 & 93 & 53 \\
\hline
\end{tabular}

\section{Data Collection Instrument}

Organizational Culture Assessment Instrument developed by Cameron and Quinn, (1999) was adopted for measuring the organizational culture of HEI. OCAI measures six dimensions of organizational culture: dominant characteristics, organizational leadership, management of employees, organization glue, strategic emphases, and criteria for success. The OCAI consists of six questions based on the aforementioned dimensions. Each question has four alternatives. The questionnaire follows a fixed sum forced-choice numeric rating scale. Respondents are supposed to divide 100 points among the given four alternatives depending on the extent to which each alternative is similar to their organization.

Several steps were followed for sharing the questionnaire and collecting data e.g. an email list (per HEI) was prepared as a first step. In the second step, an account on Monkey Survey was created and standard 
services were purchased by paying $\$ 34$. OCAI was created in the monkey survey and was tested by sending emails to a few faculty members. Upon satisfaction, the survey was shared with the created email list. Emails were sent to all faculty members. Once the emails were sent, it was found that some of the emails (mainly the non-institutional emails) were not working and the emails bounced back. Therefore additional emails were added to the list and were re-sent.

\section{Response Rate}

Response rate per HEI is given as follows:

Table-5 Response Percentage

\begin{tabular}{|c|c|c|c|c|}
\hline HEI & Population & Sample & Received & Response Percentage \\
\hline 1 & 387 & 194 & 101 & $52 \%$ \\
\hline 2 & 115 & 89 & 32 & $36 \%$ \\
\hline 3 & 163 & 115 & 7 & $6 \%$ \\
\hline 4 & 275 & 161 & 19 & $12 \%$ \\
\hline 5 & 102 & 81 & 61 & $75 \%$ \\
\hline 6 & 233 & 146 & 37 & $25 \%$ \\
\hline 7 & 334 & 179 & 36 & $20 \%$ \\
\hline 8 & 177 & 122 & 3 & $2 \%$ \\
\hline 9 & 130 & 98 & 9 & $9 \%$ \\
\hline 10 & 169 & 118 & 40 & $34 \%$ \\
\hline 11 & 315 & 174 & 55 & $32 \%$ \\
\hline 12 & 115 & 89 & 2 & $2 \%$ \\
\hline 13 & 226 & 143 & 10 & $7 \%$ \\
\hline 14 & 402 & 197 & 79 & $40 \%$ \\
\hline 15 & 119 & 92 & 3 & $3 \%$ \\
\hline 16 & 122 & 93 & 42 & $45 \%$ \\
\hline 17 & 61 & 53 & 19 & $36 \%$ \\
\hline
\end{tabular}

Out of $17 \mathrm{HEI}$, the response rate of $10 \mathrm{HEI}$ was $20 \%$ or more than $20 \%$ whereas the rest of the $07 \mathrm{HEI}$ had less than $20 \%$ response rate. Equal to or less than $20 \%$ meant that the received responses were representing less than $10 \%$ of the total population.

Furthermore, the data collection instrument i-e. OCAI relies upon arithmetic mean as the only analysis technique. Thus, HEI-3, HEI-4, HEI-8, HEI-9, HEI-12, HEI-13, HEI-15 (total of 07 HEI) were dropped from analysis i-e organizational culture profiles. The decision of dropping a stratum on lower response rate is aligned with the suggestions by J. Uttley (2019) in his article, "Power Analysis, Sample Size, and Assessment of Statistical Assumptions-Improving the Evidential Value of Lighting Research".

\section{Organizational Culture Analysis}

\section{Reliability of the Instrument}

Primary data was collected for this study, therefore it is essential to calculate the reliability statistics of the organizational culture assessment instrument (OCAI). The following table provides an overview of the reliability statistics along with maximum and minimum values for each of the dimension: 
Table-6 Reliability Statistics of OCAI

\begin{tabular}{|l|l|l|l|l|l|l|}
\hline Items & $\begin{array}{l}\text { Cronbach's } \\
\text { Alpha }\end{array}$ & $\begin{array}{l}\text { Cronbach's } \\
\text { Alpha Based on } \\
\text { Standardized } \\
\text { Items }\end{array}$ & $\begin{array}{l}\text { Number of } \\
\text { Items }\end{array}$ & Mean & $\begin{array}{l}\text { Minimu } \\
\mathbf{m}\end{array}$ & $\begin{array}{l}\text { Maximu } \\
\mathbf{m}\end{array}$ \\
\hline Clan & .814 & .814 & 6 & 28.588 & 26.996 & 30.378 \\
\hline $\begin{array}{l}\text { Adhocrac } \\
\text { y }\end{array}$ & .701 & .702 & 6 & 23.382 & 21.363 & 26.964 \\
\hline Market & .729 & .729 & 6 & 22.804 & 20.677 & 24.737 \\
\hline Hierarchy & .808 & .809 & 6 & 25.958 & 23.227 & 28.317 \\
\hline
\end{tabular}

Based on Cronbach alpha's value, the range of clan and hierarchy dimensions are good as the alpha value is within the range of $0.80-0.89$, whereas the alpha value of adhocracy and market is in the acceptable range of $0.70-0.79$.

\section{Overall Descriptive Details of Sampled KP-HEI}

The first part of the questionnaire collected demographic data of the respondent's i-e age, gender, education, designation, experience, and employment status.

Table-7 Demographic profiles of all HEI

\begin{tabular}{|c|c|c|c|}
\hline Demographics & Categories & Frequency $(n=502)$ & Percentage \\
\hline \multirow{4}{*}{ Age } & $20-29$ & 73 & $15 \%$ \\
\hline & $30-39$ & 286 & $57 \%$ \\
\hline & $40-49$ & 116 & $23 \%$ \\
\hline & 50 and Above & 27 & $5 \%$ \\
\hline \multirow{2}{*}{ Gender } & Male & 357 & $71 \%$ \\
\hline & Female & 145 & $29 \%$ \\
\hline \multirow{2}{*}{ Education } & Masters & 208 & $41 \%$ \\
\hline & Doctoral & 293 & $58 \%$ \\
\hline \multirow{4}{*}{ Designation } & Lecturer & 214 & $43 \%$ \\
\hline & Assistant Professor & 213 & $42 \%$ \\
\hline & Associate Professor & 56 & $11 \%$ \\
\hline & Professor & 19 & $4 \%$ \\
\hline \multirow{5}{*}{ Experience } & $01-05$ & 142 & $28 \%$ \\
\hline & $06-10$ & 196 & $39 \%$ \\
\hline & $11-15$ & 101 & $20 \%$ \\
\hline & $16-20$ & 34 & $7 \%$ \\
\hline & 20 and above & 29 & $6 \%$ \\
\hline \multirow{3}{*}{$\begin{array}{c}\text { Employment } \\
\text { Status }\end{array}$} & Contractual & 110 & $22 \%$ \\
\hline & BPS - Permanent & 294 & $59 \%$ \\
\hline & TTS & 98 & $20 \%$ \\
\hline
\end{tabular}

The age of respondents is represented via 04 categories with a minimum age of 20 and a maximum above $50.57 \%$ of the faculty members are 30 to 39 years old whereas $23 \%$ are 40 to 49 years of age. $29 \%$ of the total 502 faculty members are female whereas the rest of $71 \%$ are male. On the education index of the respondents, $58 \%$ of the faculty members of the survey have a doctoral degree whereas $41 \%$ are master's degree holders. In HEI the number of lecturers is higher followed by assistant professor, associate professor, and then full professor. The same trend can be observed with this data set, $43 \%$ of the faculty 
members who took part in the survey are lectures with $42 \%$ assistant professors, $11 \%$ associate professors, and $4 \%$ professors. The maximum experience range is 06 to 10 years, i-e. $39 \%$ of the sampled faculty members have been the part of the current HEI for a period of 6 to 10 years, $28 \%$ have been serving current HEI for about 1 to 05 years, $20 \%$ for 11-15 years and $6 \%$ of the sampled faculty members have served the current HEI for more than 20 years at the time of the survey. Whereas approximately $59 \%$ of sampled faculty members are in BPS/SPS permanent scale.

\section{Competing values: Internal-External vs. Stability-Flexibility Dimensions}

The competing values developed by Quinn and Rohrbaugh, (1981) are based on two dimensions i-e Internal-External dimensions vs Stability-Flexibility dimension. The following table provides a mean average of HEI data and highlights the HEI orientation. Internal orientation means that the institution has an inward focus related to development, collaboration, coordination, and integration. Whereas the external focus means that the institution looks outside i.e. the market for development, collaboration, coordination, and integration by keeping an eye on competitors and the latest technologies. Since the dimension is part of 'competing' values, therefore, Quinn and Rohrbaugh (1981) suggest that institutions cannot have both orientations at the same time.

Table-8 Internal-External Dimensions of KP-HEI

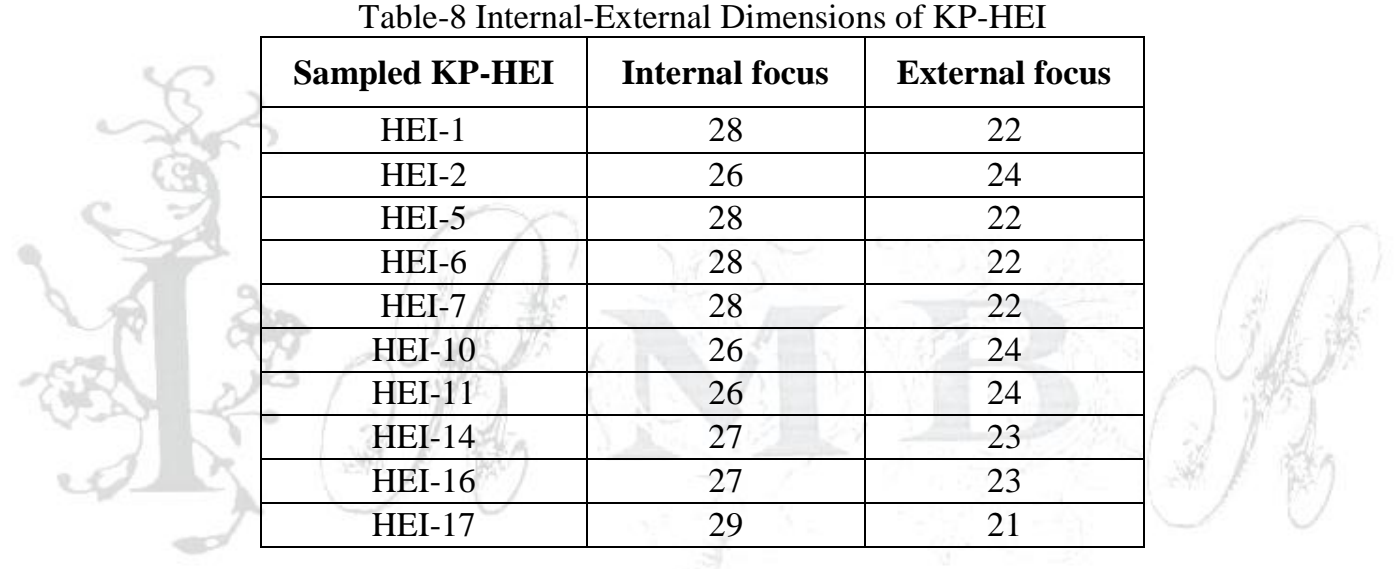

It is evident from the table above that almost all public sector HEIs in KP have an inward or internal orientation. The HEI development, collaborations, integration of activities, and coordination are all internally driven.

The second competing value is an institutional focus on stability (control) or flexibility. Institutions with stability orientation focus on controlling reality. Such institutions value defined structure, plans, budgets, and reliability. Institutions with stability focus stay focused on whatever is planned already with no flexibility at all. On the other side, institutions with flexibility orientation prefer elastic attitudes and value people and activities as opposed to defined structures, procedures, and plans. Given the nature of both dimensions, institutions cannot have both at the same time. The following table provides a glimpse of KPHEI orientation on the aforementioned dimensions:

Table-9 Stability-Flexibility Dimension of KP-HEI

\begin{tabular}{|c|c|c|}
\hline Sampled KP-HEI & Flexibility & Stability/ Control \\
\hline HEI-1 & 27 & 23 \\
\hline HEI-2 & 26 & 24 \\
\hline HEI-5 & 24 & 26 \\
\hline HEI-6 & 25 & 25 \\
\hline HEI-7 & 28 & 22 \\
\hline
\end{tabular}




\begin{tabular}{|c|c|c|}
\hline HEI-10 & 24 & 26 \\
\hline HEI-11 & 26 & 24 \\
\hline HEI-14 & 26 & 24 \\
\hline HEI-16 & 26 & 24 \\
\hline HEI-17 & 26 & 24 \\
\hline
\end{tabular}

HEI-5 and HEI-10 are the only two public sector higher educational institutions with stability or control orientation whereas the rest of the HEI in KP are predominantly flexible. HEI-06 though has an equal score on both dimensions meaning it focuses on both orientations.

\section{Types of Organizational Cultures of KP-HEI}

Organizational culture types emerge by plotting the competing values, discussed above. The $2 \times 2$ matrix results in 04 organizational culture types: clan, adhocracy, market, and hierarchy culture. Organizational Culture types of sampled KP-HEI are given below:

Table-10 Organizational Culture Types of KP-HEI

\begin{tabular}{|c|c|c|c|c|}
\hline Sampled KP-HEI & Clan & Adhocracy & Market & Hierarchy \\
\hline HEI-1 & 31 & 21 & 22 & 25 \\
\hline HEI-2 & 26 & 25 & 23 & 25 \\
\hline HEI-5 & 27 & 21 & 23 & 28 \\
\hline HEI-6 & 28 & 22 & 23 & 27 \\
\hline HEI-7 & 31 & 24 & 21 & 24 \\
\hline HEI-10 & 26 & 22 & 27 & 26 \\
\hline HEI-11 & 26 & 25 & 23 & 26 \\
\hline HEI-14 & 28 & 23 & 23 & 26 \\
\hline HEI-16 & 28 & 23 & 23 & 26 \\
\hline HEI-17 & 31 & 22 & 20 & 28 \\
\hline
\end{tabular}

The culture with higher mean value is considered to be the dominant organizational culture type of the sample institution. According to Cameron and Quinn organizational culture is a mix of the four types and thus has one predominant type as opposed to one single particular type. In light of the above table, it can be deduced that clan and hierarchy cultures are the dominant cultures of KP-HEI. For ease of discussion and analysis data presented above is reorganized as follows:

Table-11 Summary of Org. Culture Types of HEI in KP

\begin{tabular}{|c|c|}
\hline Sampled KP-HEI & Dominant Org. Culture \\
\hline HEI-1 & Clan \\
\hline HEI-2 & Clan \\
\hline HEI-5 & Hierarchy \\
\hline HEI-6 & Clan \\
\hline HEI-7 & Clan \\
\hline HEI-10 & Market \\
\hline HEI-11 & Clan and Hierarchy \\
\hline HEI-14 & Clan \\
\hline HEI-16 & Clan \\
\hline HEI-17 & Clan \\
\hline
\end{tabular}


The majority of the sampled KP-HEI have clan culture as the predominant culture with exception to HEI-5 which has a hierarchy culture, HEI-10 with market culture, and HEI-11 that has clan and hierarchy as predominant organizational culture. According to OCAI, organizations with a clan or collaborative cultures are like families, employees have a lot in common and a lot to share too. Such organizations are defined by mutual trust, loyalty and tradition. The emphasis of the organization in long term human resource development. Teamwork, participation and consensus are highly appreciated. HEI-5 has a hierarchy culture. A hierarchy or control culture represents formal and structured institutions. The smooth functioning of the organization, efficiency-based coordination, formal policies and procedures prioritized and practiced in such institutions. HEI-11, however, share clan and hierarchy cultures. This means that the institution share or exhibit properties of both cultures outlined above. Only one HEI i-e HEI-10 has a market or compete for culture as its predominant culture type. Institutions with such cultures are result oriented and driven by market competition. Leaders of such institutions are highly demanding and commanding. Employees of such organizations are very competitive and totally focused on goals and results. None of the sampled public sector HEI in KP has an adhocracy or create culture. Institutions with such cultures are dynamic, risk-takers, entrepreneurial and visionary.

\section{Dominant Characteristics of Sampled KP-HEI Cultures}

\section{Dominant Characteristic}

The dominant characteristic intends to identify the one single characteristic that the members of the organization define the organization from or affiliates the organization. The statements with higher mean value are considered to be the dominant characteristic of the institution.

Table-12 Dominant Characteristics of HEI

\begin{tabular}{|c|c|c|c|c|c|c|c|c|c|c|c|}
\hline & 1. Dominant Characteristics & HEI-1 & $\mathrm{HEI}-2$ & HEI-5 & HEI- 6 & HEI-7 & HEI-10 & HEI-11 & HEI-14 & HEI-16 & HEI-17 \\
\hline B & $\begin{array}{l}\text { The organization is a very dynamic } \\
\text { and entrepreneurial place. People are } \\
\text { willing to stick their necks out and } \\
\text { take risks. }\end{array}$ & 22 & 22 & 21 & 18 & 22 & 21 & 20 & 24 & 23 & 16 \\
\hline $\mathrm{C}$ & $\begin{array}{l}\text { The organization is very results- } \\
\text { oriented. A major concern is with } \\
\text { getting the job done. People are very } \\
\text { competitive and achievement- } \\
\text { oriented. }\end{array}$ & 28 & 27 & 22 & 24 & 21 & 29 & 20 & 23 & 29 & 26 \\
\hline
\end{tabular}

HEI-1, 2, 10, and 16 are similar, as the dominant characteristic of these HEIs is result-oriented. The faculty of the institutions are competitive and achievement-oriented. In HEI-6, 11, 14, and 17, the faculty believes that the institution is a structured and controlled entity. Formal procedures generally govern the operations of the institution. In HEI-5 and HEI-7 the perception of faculty is that the institution's culture is like a family. Faculty share a lot with one another and consider the institution as a personal place.

\section{Organizational Leadership}

This aspect represents the perception of the employees about organizational leadership. Four alternative statements are given and the one with higher mean value is considered to be the organizational leadership 
style as perceived by the employees of an organization. The following tables and a graph exhibits the organizational leadership style of KP-HEI as perceived by faculty members of the HEI.

Table-13 Organizational Leadership of HEI

\begin{tabular}{|c|c|c|c|c|c|c|c|c|c|c|c|}
\hline \multicolumn{2}{|c|}{ 2. Organizational Leadership } & HEI-1 & HEI-2 & HEI-5 & HEI-6 & HEI-7 & HEI-10 & HEI-11 & HEI-14 & HEI-16 & HEI-17 \\
\hline A & $\begin{array}{l}\text { The leadership in the organization is } \\
\text { generally considered to exemplify } \\
\text { mentoring, facilitating, or nurturing. }\end{array}$ & 28 & 25 & 26 & 26 & 31 & 27 & 27 & 28 & 31 & 34 \\
\hline B & $\begin{array}{l}\text { The leadership in the organization is } \\
\text { generally considered to exemplify } \\
\text { entrepreneurship, innovation, or risk } \\
\text { taking. }\end{array}$ & 23 & 27 & 20 & 22 & 21 & 21 & 24 & 23 & 23 & 19 \\
\hline C & $\begin{array}{l}\text { The leadership in the organization is } \\
\text { generally considered to exemplify a } \\
\text { no-nonsense, aggressive, results- } \\
\text { oriented focus. }\end{array}$ & 19 & 21 & 24 & 25 & 17 & 24 & 21 & 23 & 19 & 17 \\
\hline D & $\begin{array}{l}\text { The leadership in the organization is } \\
\text { generally considered to exemplify } \\
\text { coordinating, organizing, or smooth- } \\
\text { running efficiency. }\end{array}$ & 30 & 27 & 30 & 26 & 31 & 28 & 28 & 26 & 26 & 29 \\
\hline
\end{tabular}

The organizational leadership of HEI-1, 2, 5, 10 and 11 is focused on smooth-running efficiency, coordination. The leadership style of HEI-6, 7, 14, 16 and 17 is focused on mentoring, facilitating, or nurturing. Leadership style in HEI-2 is the only HEI that focuses on entrepreneurship, innovating and risktaking. HEI-2, and 6 and 7 share characteristics of coordination, organizing and smooth-running efficiency.

\section{Management of Employees}

The third aspect is about the employees' perception of the prevailing management style in an organization. This aspect covers the way management of an organization deal with employees, takes decisions, plan and organize work and the way authority is exercised. The alternative statement with a higher mean value is considered to be the prevailing dominant management style of employees. The following tables and a graph shows the respective styles of management of employees in HEI of KP.

Table-14 Management of Employees

\begin{tabular}{|c|c|c|c|c|c|c|c|c|c|c|c|}
\hline \multicolumn{2}{|r|}{ 3. Management of Employees } & HEI-1 & HEI-2 & HEI-5 & HEI-6 & HEI-7 & HEI-10 & HEI-11 & HEI-14 & HEI-16 & HEI-17 \\
\hline A & $\begin{array}{l}\text { The management style in the organization } \\
\text { is characterized by teamwork, consensus, } \\
\text { and participation. }\end{array}$ & 32 & 27 & 26 & 28 & 38 & 27 & 27 & 28 & 28 & 31 \\
\hline B & $\begin{array}{l}\text { The management style in the organization } \\
\text { is characterized by individual risk taking, } \\
\text { innovation, freedom, and uniqueness. }\end{array}$ & 19 & 26 & 24 & 25 & 25 & 21 & 25 & 22 & 22 & 23 \\
\hline C & $\begin{array}{l}\text { The management style in the organization } \\
\text { is characterized by hard-driving } \\
\text { competitiveness, high demands, and } \\
\text { achievement. }\end{array}$ & 26 & 22 & 24 & 25 & 21 & 32 & 23 & 24 & 23 & 18 \\
\hline D & $\begin{array}{l}\text { The management style in the organization } \\
\text { is characterized by security of } \\
\text { employment, conformity, predictability, } \\
\text { and stability in relationships. }\end{array}$ & 20 & 25 & 27 & 22 & 17 & 20 & 24 & 26 & 26 & 29 \\
\hline
\end{tabular}

The management style in the majority of HEI is participatory where decisions are taken with mutual consensus and teamwork is considered a key factor in planning and coordinating. The management style of HEI-5 focuses on predictability and stability of relationships in planning, organizing, coordinating and 
leading. The only HEI with a demanding and competitive management style is HEI-10 as it focuses on achievements while planning, organizing, leading and controlling.

\section{Organization Glue}

Organization glue is about the factor/s that bring the organization together. This aspect helps in understanding the bonding factors among the organizational members. The following tables and graphs show the mean values assigned by faculty members. The higher mean value represents the dominant factors that shape the organization or glue it together as an organization.

Table-15 Organizational Glue of HEI

\begin{tabular}{|c|c|c|c|c|c|c|c|c|c|c|c|}
\hline \multicolumn{2}{|c|}{ 4. Organization Glue } & HEI-1 & HEI-2 & HEI-5 & HEI-6 & HEI-7 & HEI-10 & HEI-11 & HEI-14 & HEI-16 & HEI-17 \\
\hline A & $\begin{array}{l}\text { The glue that holds the organization } \\
\text { together is loyalty and mutual trust. } \\
\text { Commitment to this organization runs } \\
\text { high. }\end{array}$ & 36 & 26 & 30 & 30 & 28 & 27 & 23 & 31 & 31 & 36 \\
\hline B & $\begin{array}{l}\text { The glue that holds the organization } \\
\text { together is commitment to innovation } \\
\text { and development. There is an } \\
\text { emphasis on being on the cutting } \\
\text { edge. }\end{array}$ & 25 & 27 & 20 & 21 & 26 & 27 & 27 & 21 & 21 & 26 \\
\hline $\mathrm{C}$ & $\begin{array}{l}\text { The glue that holds the organization } \\
\text { together is the emphasis on } \\
\text { achievement and goal } \\
\text { accomplishment. }\end{array}$ & 20 & 24 & 25 & 23 & 24 & 23 & 21 & 23 & 20 & 16 \\
\hline D & $\begin{array}{l}\text { The glue that holds the organization } \\
\text { together is formal rules and policies. } \\
\text { Maintaining a smooth-running } \\
\text { organization is important. }\end{array}$ & 19 & 23 & 25 & 25 & 22 & 23 & 29 & 25 & 27 & 22 \\
\hline
\end{tabular}

Mutual trust, commitment, and loyalty hold all HEI in KP together with exception to HEI-2 and 11. Faculty in HEI-2 considers commitment to innovation as the binding glue of an organization, HEI-10 also shares this characteristic with HEI-2. Whereas for HEI-11formal rules and policies are the reasons behind the tight knitting of the HEI. For them, the smooth running of the organization is the reason behind being together.

\section{Strategic Emphasis}

The fifth aspect of organizational culture is the strategic emphasis of organizations. This aspect helps in understanding the factors that are considered important and are prioritized by an organization while strategizing. Like the rest of the aspects, this dimension also provides the respondents with four alternatives, and the one with higher mean value is considered to be the prevailing dominant characteristic. Following tables and graphs provides an overview of this aspect:

Table-16 Strategic Emphasis of HEI

\begin{tabular}{|c|c|c|c|c|c|c|c|c|c|c|c|}
\hline \multicolumn{2}{|c|}{ 5. Strategic Emphases } & HEI-1 & HEI-2 & HEI-5 & HEI-6 & HEI-7 & HEI-10 & HEI-11 & HEI-14 & HEI-16 & HEI-17 \\
\hline A & $\begin{array}{l}\text { The organization emphasizes human } \\
\text { development. High trust, openness, and } \\
\text { participation persist. }\end{array}$ & 36 & 27 & 24 & 29 & 32 & 28 & 28 & 27 & 26 & 24 \\
\hline B & $\begin{array}{l}\text { The organization emphasizes acquiring } \\
\text { new resources and creating new } \\
\text { challenges. Trying new things and } \\
\text { prospecting for opportunities are valued. }\end{array}$ & 23 & 25 & 23 & 21 & 26 & 19 & 26 & 24 & 26 & 25 \\
\hline C & $\begin{array}{l}\text { The organization emphasizes } \\
\text { competitive actions and achievement. } \\
\text { Hitting stretch targets and winning in the } \\
\text { marketplace are dominant. }\end{array}$ & 17 & 21 & 20 & 22 & 19 & 23 & 21 & 23 & 24 & 19 \\
\hline D & $\begin{array}{l}\text { The organization emphasizes } \\
\text { permanence and stability. Efficiency, } \\
\text { control, and smooth operations are } \\
\text { important. }\end{array}$ & 24 & 28 & 32 & 27 & 23 & 30 & 25 & 27 & 26 & 31 \\
\hline
\end{tabular}


HEI-1, 6, 7, 11, 14 and 16 emphasize human development while strategizing. The focus of the mentioned HEI is on trust, openness and participation while planning for the future. Whereas, HEI-2, 5, 10 and 17 emphasize permanence and stability in strategic priorities. These institutions focus on efficiency, control, and smooth running of the HEI in setting future goals. HEI-16 shares both the characteristics of trust and stability as a strategic emphasis. However, none of the sampled institutions emphasizes the acquisition of new resources and creating new challenges as strategic priorities. Similarly, none of the sampled HEI in KP consider competitive actions and achievement as strategic emphasis.

\section{Criteria of Success}

The final aspect of organizational culture in OCAI is the criteria of success. This aspect provides an insight into the definition or criteria of success by an organization. The option with higher mean value is considered to the defining aspect of success by the organization.

Following tables and graphs provide an insight into the KP-HEI definition of success:

Table-17 Criteria of Success in HEI

\begin{tabular}{|c|c|c|c|c|c|c|c|c|c|c|c|}
\hline \multicolumn{2}{|c|}{ 6. Criteria of Success } & \multirow{2}{*}{$\begin{array}{r}\text { HEI-1 } \\
31\end{array}$} & \multirow{2}{*}{$\begin{array}{l}\text { HEI-2 } \\
27\end{array}$} & \multirow{2}{*}{$\begin{array}{r}\text { HEI-5 } \\
26\end{array}$} & \multirow{2}{*}{$\begin{array}{l}\text { HEI-6 } \\
30\end{array}$} & \multirow{2}{*}{$\begin{array}{r}\text { HEI-7 } \\
28\end{array}$} & \multirow{2}{*}{$\begin{array}{r}\text { HEI-10 } \\
22\end{array}$} & \multirow{2}{*}{$\begin{array}{r}\text { HEI-11 } \\
24\end{array}$} & \multirow{2}{*}{$\begin{array}{l}\text { HEI-14 } \\
29\end{array}$} & \multirow{2}{*}{$\begin{array}{r}\text { HEI-16 } \\
29\end{array}$} & \multirow{2}{*}{$\begin{array}{r}\text { HEI-17 } \\
31\end{array}$} \\
\hline A & $\begin{array}{l}\text { The organization defines success on } \\
\text { the basis of the development of human } \\
\text { resources, teamwork, employee } \\
\text { commitment, and concern for people. }\end{array}$ & & & & & & & & & & \\
\hline B & $\begin{array}{l}\text { The organization defines success on } \\
\text { the basis of having the most unique or } \\
\text { newest products. It is a product leader } \\
\text { and innovator. }\end{array}$ & 17 & 26 & 21 & 22 & 26 & 20 & 26 & 23 & 25 & 23 \\
\hline C & $\begin{array}{l}\text { The organization defines success on } \\
\text { the basis of winning in the marketplace } \\
\text { and outpacing the competition. } \\
\text { Competitive market leadership is key. }\end{array}$ & 23 & 22 & 24 & 20 & 22 & 32 & 28 & 22 & 23 & 22 \\
\hline D & $\begin{array}{l}\text { The organization defines success on } \\
\text { the basis of efficiency. Dependable } \\
\text { delivery, smooth scheduling, and low- } \\
\text { cost production are critical. }\end{array}$ & 29 & 25 & 29 & 28 & 24 & 26 & 22 & 26 & 28 & 24 \\
\hline
\end{tabular}

HEI-1, 2, 6, 7, 14, 16 and 17 definitions of success are based on HR development. Teamwork, commitment and concern for people is considered critical for success. HEI-5 defines success via efficiency. The institution believes that smooth scheduling, dependable delivery, and low-cost operations are vital for success. HEI-10 and 11 are the only two HEI in KP that define success in terms of market share and competition. Both institutions consider competitive market leadership as a criterion of success. However, none of the HEI defines success based on uniqueness and innovation. Product leadership and innovation are still not considered to be the criteria of success in KP-HEI.

Organizational culture profiles developed based on the aforementioned analysis are given in appendix-I.

\section{Comparison of KP-HEI Cultures with Knowledge-Based Organizational Cultures}

Characteristics of knowledge-based cultures were adapted from literature. The developed characteristics of knowledge cultures are compared with KP-HEI organizational profiles in the following table. The comparison is based on the data extracted from six aspects of organizational culture given in OCAI. The comparison of KP-HEI organizational profiles with that of knowledge-based culture characteristics shows that almost all the HEI in KP cannot be labeled as completely knowledge-based. Interaction opportunities provisions are the only characteristic of KP-HEI that matches knowledge-based HEI, the remaining characteristics are not fully complied with. 
Table-18 Comparison of KP-HEI with Characteristics of Knowledge-Based Cultures

\begin{tabular}{|c|c|c|c|c|c|c|c|c|c|}
\hline \multirow[b]{2}{*}{ HEI } & \multicolumn{5}{|c|}{ Organizational Level Characteristics } & \multicolumn{4}{|c|}{ Managerial Level } \\
\hline & $\begin{array}{l}\text { Leadership } \\
\text { Supports } \\
\text { Risk } \\
\text { Taking } \\
\text { and } \\
\text { innovation }\end{array}$ & $\begin{array}{c}\text { Knowledge } \\
\text { Monitoring } \\
\text { and } \\
\text { governance } \\
\text { strategy }\end{array}$ & $\begin{array}{c}\text { Knowledge } \\
\text { leverage } \\
\text { strategy }\end{array}$ & $\begin{array}{l}\text { Knowledge- } \\
\text { based } \\
\text { rewards and } \\
\text { incentives }\end{array}$ & $\begin{array}{l}\text { Central } \\
\text { database } \\
\text { for } \\
\text { knowledge } \\
\text { tracking } \\
\text { and } \\
\text { integration }\end{array}$ & $\begin{array}{c}\text { KM based } \\
\text { orientation } \\
\text { and } \\
\text { socialization } \\
\text { policy }\end{array}$ & $\begin{array}{l}\text { Team- } \\
\text { Based } \\
\text { job } \\
\text { design }\end{array}$ & $\begin{array}{l}\text { Knowledge- } \\
\text { based staff } \\
\text { development } \\
\text { policy }\end{array}$ & $\begin{array}{c}\text { Promotive } \\
\text { Interaction } \\
\text { opportunities }\end{array}$ \\
\hline HEI-1 & $x$ & $x$ & $x$ & $x$ & $x$ & $x$ & $\checkmark$ & $x$ & $\checkmark$ \\
\hline HEI-2 & $\checkmark$ & $x$ & $x$ & $x$ & $x$ & $x$ & $\checkmark$ & $x$ & $\checkmark$ \\
\hline HEI-5 & $x$ & $x$ & $x$ & $x$ & $x$ & $x$ & $x$ & $x$ & $\checkmark$ \\
\hline HEI-6 & $x$ & $x$ & $x$ & $x$ & $x$ & $x$ & $\checkmark$ & $x$ & $\checkmark$ \\
\hline HEI-7 & $x$ & $x$ & $x$ & $x$ & $x$ & $x$ & $\checkmark$ & $x$ & $\checkmark$ \\
\hline HEI-10 & $x$ & $x$ & $x$ & $\checkmark$ & $x$ & $x$ & $\checkmark$ & $x$ & $\checkmark$ \\
\hline HEI-11 & $x$ & $x$ & $x$ & $\checkmark$ & $x$ & $x$ & $\checkmark$ & $x$ & $\checkmark$ \\
\hline HEI-14 & $x$ & $x$ & $x$ & $x$ & $x$ & $x$ & $\checkmark$ & $x$ & $\checkmark$ \\
\hline HEI-16 & $x$ & $x$ & $x$ & $x$ & $x$ & $x$ & $\checkmark$ & $x$ & $\checkmark$ \\
\hline HEI-17 & $x$ & $x$ & $x$ & $x$ & $x$ & $x$ & $\checkmark$ & $x$ & $\checkmark$ \\
\hline
\end{tabular}

\section{Discussion}

The organizational culture data collected from 10 KP-HEI doesn't represent the HEC envisioned culture. 07 out of 10 HEI have clan culture as the dominant organizational culture, 02 HEI has a hierarchy culture as dominant organizational culture.

$08 \mathrm{HEI}$ of KP has a clan culture meaning they operate like a family or tribe, a high level of cooperation within and between groups. Such a culture advocates commonality and consensus of values and goals. Cameron and Quinn (1999) defines clan cultures as high on collaboration but low on competitiveness. Critics of clan culture argue that organizations following such a culture lacks diversity and emphasizes cohesiveness. Furthermore, clan culture premiums teamwork and conformity, thus, conflict of opinion or viewpoints are generally not welcomed. Decisions in clan culture are made by common agreement therefore the clear line of authority is difficult to define. The challenge for HEI is that they do not operate in isolation, they frequently interact with the external environment and clan culture may not support transfer outside the HEI as clan culture lack competitiveness.

HEC expects HEI to be innovative, entrepreneurial, and commercial, the analyzed organizational culture of 08 HEI is collaborative, and conformity oriented and opposes diversity (in views and opinions). The findings of the study are aligned with Pineda et. al. 2010 meta-analysis. Where the authors concluded that clan culture is the most practiced culture in contemporary HEI but service HEI that focuses on innovation and commercialization adhocracy and market culture is the most suitable. Such a high number of HEI having clan culture as the predominant culture is aligned with Wilson's (2012) argument, that tribalism is the fundamental human behavior and thus people are a given set-up will confer to such behaviors. $02 \mathrm{KP}$ HEI has hierarchical cultures. Cameron and Quinn (1999), defines hierarchy culture as a controlled and structured entity, where top-down controls are in place. Critics of hierarchy culture are of the opinion that control and rigidity of rules stifle creativity, innovation, and employee initiatives. Comparing the $02 \mathrm{HEI}$ hierarchical cultures with that of HEC envisioned future of HEI, it can be inferred that HEC wants HEI to be creative and market lead rather than being professional bureaucracies (Mintzberg, 1983 considered traditional HEI as professional bureaucracies). Hierarchical culture is an indication that the classical management model is applied in the mentioned institutions. Beytekin et al., 2010 suggest that HEIs with hierarchical cultures are not suitable for innovative practices as the culture provides insufficient flexibility for creative endeavors.

All of the 10 sampled KP-HEI have an internal orientation. Competing value framework defines organizations with internal orientation as organizations that focus on internal development, collaboration, 
and integration of activities. It can be inferred that HEI in KP are driven by internal development motive as opposed to market competition. Though internal orientation is fruitful for long term development, the priority of internal or external orientation is based on the alignment with the mission or strategic goal. Clearly, the goal of surviving in the knowledge economy demands HEI in KP to look outside and match and compete with the market trends. The findings on flexibility vs stability orientation are very progressive as the majority of the HEI are flexible with exception to HEI-5 and HEI-10. Competing value framework considers organizations with flexibility orientation as an organization that values people and activities as opposed to structures and procedures. Such organizations adapt quickly to changing circumstances. Weinstein (1998) considers communicational channels and free flow of information as characteristics of flexible organizations. HEI who have scored high on flexibility orientation of the study have clearly defined laws i-e University ACT 2012 and have active faculty and staff bodies representing faculty and staff point of view. Clear procedural layout and representative platforms provision brings flexibility in orientation compared to ambiguous policies and lack of representative forums. HEC can utilize this flexibility orientation of HEI in KP for initiating long term organizational cultural interventions for aligning the HEI with the envisioned future. Further studies are recommended to understand the nature of the flexible orientation of HEI, so to identify the strength and weaknesses in HEI orientation.

The sampled HEI have shown a variety of dominant characteristics, 04 out of 10 HEI perceives the organizational culture as result-oriented, competitive and achievement-oriented, again 04 out $10 \mathrm{HEI}$ consider the organizational culture as a tight structure led by rules, whereas only 02 HEI consider HEI as a family or personal space, knotted together via trust. None of the HEI is believed to be a dynamic and entrepreneurial place. This is an alarming trend, specifically with HEC 2025 vision. Literature advocates that people shape organizational culture and organizational culture impacts the performance of the organization in return. None of the sampled 502 faculty members consider HEI to be dynamic and entrepreneurial, thus it will be difficult for HEC to achieve the intended knowledge-based organizational culture orientation.

The same trend can be observed in organizational leadership. 05 HEI out of 10 considers that the leadership of the HEI is focused on the smooth running of the HEI and coordination. The dominant leadership characteristic of HEI is aligned with clan cultures. The reaming $05 \mathrm{HEI}$ believe that the leadership is more focused on nurturing, mentoring and facilitation. Leadership is not only the index of an organization's strategic orientation but is also the anchor of an organization's mission and vision. If none of the 502 faculty members surveyed, with 39\% having 6-10 years of experience in the current HEI consider the leadership as exemplifying entrepreneurship, innovation, risk-taking and result orientation then its high time for HEC to consider organizational culture and leadership of HEI as its next development agenda.

The third characteristic of organizational culture assessed via OCAI is the management style of HEI i-e how faculty perceive they are managed in respective HEI. Since the majority of the HEI have a clan culture therefore the management style is reflective of it i-e participatory. 9 out of 10 HEI consider teamwork and participation as the dominant management style with exception to HEI-5 where the management style is characterized by employment security, conformity and predictability. Again, none of the HEI consider the prevailing HEI management style to be characterized by risk-taking, innovation, freedom, and competitiveness and high demands. Survival in knowledge economy and achievement of HEC 2025 vision requires revamping of the management style of HEI. HEI must have a more competitive and innovative management style.

Organizational glue is the fourth aspect of organizational culture assessment. 08 out of $10 \mathrm{HEI}$ consider mutual trust, commitment, and loyalty as the knitting order of the HEI. This is again congruent with clan culture characteristics. Whereas for HEI-11formal rules and policies are the reasons behind the tight knitting of the HEI. HEI-2 is the only KP-HEI that considers commitment to innovation as the binding agent of the institution. None of the sampled HEI consider achievement, goal accomplishment or winning common themes as the glue that holds the organization together. As the organizational culture assessment 
digs deep, the dis-association between the envisioned 2025 tomorrow and prevailing traditional HEI cultures are becoming clearer. The most important aspect of an organization is its strategic emphasis, 06 out of 10 surveyed HEI consider human development, participation, high trust as the center of its strategic planning and objectives, whereas for the remaining $04 \mathrm{HEI}$, the strategy focuses on stability, permanence, control and smooth operations. None of the sampled HEI focuses on acquiring new resources and creating challenges or on achievement and competitive edge. This again is aligned with the internal orientation of $\mathrm{KP}-\mathrm{HEI}$ and with clan culture as the dominant organizational culture. The final aspect is the definition of success within HEI. The trend remains the same and aligned with clan culture having internal orientation. 07 out of 10 HEI perceive and define success on the basis of HR development, teamwork and employee commitment. HEI-5 considers efficiency, dependable delivery, and smooth functioning as a success. HEI10 and 11 are the only two HEI in KP that define success in terms of market share and competition. Both institutions consider competitive market leadership as criteria of success. However, none of the HEI defines success based on uniqueness and innovation. Product leadership and innovation are still not considered to be the criteria of success in KP-HEI.

The characteristics of organizational cultures of sampled KP-HEI were compared to knowledge-based cultures. Though the given comparison is a mere characteristic matching of the organizational culture profiles with knowledge-based cultures and lacks statistical rigor yet the comparison is done to develop an overview of the surveyed cultures. The dimensions of organizational cultures that could be matched with the identified profiles are marked as present or absent whereas, few of the characteristics are subject to ToK index data. Therefore the entire table is completed in the last stage of the study and is discussed accordingly. However, for this section, in view of the prior discussion and comparison table, it can be inferred that the organizational cultures of KP-HEI cannot be labeled as knowledge-based cultures regardless of the fact that HEC has initiated a number of interventions for aligning HEI with its envisioned future e.g. establishment of Offices of Research, Innovation and Commercialization (ORIC), Quality Enhancement Cells (QEC), Modern University Governance Program (MUG) etc.

\section{Conclusion}

The study based on organizational culture assessment of $10 \mathrm{KP}$-HEI concludes that organizational culture of HEI in KP are that of traditional universities with clan cultures as predominant organizational culture and internal focus. The leadership, strategic focus, and definition of success criteria are mainly driven by the smooth functioning of the HEI, efficiency, coordination and maintaining the status quo. None of the sampled HEI have exhibited characteristics of an entrepreneurial educational institution that focuses on innovation, risk-taking and competitive and high demands based on market needs. HEC has initiated several interventions but has not taken into account the organizational culture of HEI operating in the country. Each HEI is a system with dominant culture and several sub-cultures at the same time. HEC must focus on the organizational cultures of the HEI is it wants to achieve its 2025 vision of making HEI as enabling and leading centers of transition into a knowledge economy. On the basis of the current organizational data set the only conclusion is that in 2020 the HEI in KP are still state-funded research organizations layered on top of the teaching organization, strictly following the Humboldt Model. This study supports Pfeffer and Sutton (2000) and Alavi and Leidner (2001), where they advocated that people in an organization may be knowledgeable and willing to share knowledge but they do not act upon doing subject to lack of incentives for knowledge-based cultures.

\section{Future Research Insights}

The study recommends the following future research directions that will assist in understanding the organizational cultures of HEI:

i. Comparative analysis of organizational culture typologies based on organizational culture theories versus organizational culture typologies based on Institutional theory in Higher Education Institutions.

ii. Analysis of sub-cultures within HEI using qualitative methodology. 


\section{Limitations of the Study}

The study faced some limitations e.g. OCAI uses a forced-choice numerical scale that was considered difficult to attempt by a number of faculty members. Faculty members who participated in the survey contacted the researcher about the difficulty in filling the survey as for them dividing 100 marks into four alternative statements was challenging. This lead to a low response rate in the organizational culture survey. Furthermore, the online data collection technique was another limitation of the study. As the requested email automatically was directed towards spam email categories and thus remained unanswered. This again led to the low response rate in the organizational culture survey.

\section{References}

Agasisti, T., \& Johnes, G. (2015). Efficiency, costs, rankings and heterogeneity: the case of US higher education. Studies in Higher Education, 40(1), 60-82.

Alavi, M. \& Leidner D. E. (2001). Knowledge management and knowledge management systems, Conceptual foundations and research issues. MIS quarterly, 107-136.

Antić, M., \& Cerić, A. (2008, January). Organizational culture of faculty of civil engineering, University of Zagreb. In International Conference: Organization, Technology and Management in Construction (8; 2008).

Bartell, M. (2003). Internationalization of universities, A university culture-based framework. Higher education 45(1), 43-70.

Bashir, M., Jianqiao, L., Abrar, M., \& Ghazanfar, F. (2012). The organization's cultural values: A study of public sector universities in Pakistan. African Journal of Business Management, 6(10), 3686-3693.

Beytekin, O. F., Yalçınkaya, M., Doğan, M., \& Karakoç, N. (2010). The organizational culture at the university. The International Journal of Educational Researchers 2(1), 1-13.

Bollinger, A. S., \& Smith, R. D. (2001). Managing organizational knowledge as a strategic asset. Journal of knowledge management.

Bruneel, J., D'Este, P., Neely, A. \& Salter, A. (2009). The search for talent and technology. AIM research paper, Imperial College London.

Bruneel, J., Moray, N. \& Clarysse, B (2009). Formal technology transfer mechanisms in context, the case of publicly funded universities. ISPIM, ISPIM.

Cameron, K. S. \& Quinn R. E (1999). An introduction to changing organizational culture. Diagnosing and Changing Organizational Culture, Based on the Competing Values Framework, 1-17.

Clark, B. R. (1998). Creating entrepreneurial universities, Organizational pathways of transformation. Issues in higher education, ERIC.

Cohen, M. P. (1998). Determining sample sizes for surveys with data analyzed by hierarchical linear models. Journal of Official Statistics, 14(3), 267.

Cummings, W. K. T. (1995). The Service University. Paper presented at the annual conference of the Comparative and International Education Society. Boston.

Davenport, T. H. \& L. Prusak (1998). Working knowledge, How organizations manage what they know, Harvard Business Press.

Davies, R. (1996). Industry-university collaborations, a necessity for the future. Journal of Dentistry 24(12), 3-5.

De Long, D. (1997). Building the knowledge-based organization, How culture drives knowledge behaviors. Centers for Business Innovation-Working Paper, 1-29.

Desson, K., \& Clouthier, J. (2010, November). Organizational culture-why does it matter. In Symposium on International Safeguards International Atomic Energy Agency Vienna, Austria (pp. p3-4).

Dill, D. D. (1992). Quality by design, Toward a framework for academic quality management. Higher education, Handbook of theory and research 8, 37-83.

Docherty, D., Herrmann, K. \& Ternouth, P. (2010). Absorbing Research, The role of university research in business and market innovation. CIHE, Council for Industry and Higher Education. London. UK. 
Enros, P. C. \&. Farley M. R (1986). University offices for technology transfer, toward the service university, Science Council of Canada.

European Commission (2007). Improving knowledge transfer between research institutions and industry across Europe, embracing open innovation-Implementing the Lisbon agenda, Author Brussels.

Irwin, H. \& More E. (1991). Technology transfer and communication, lessons from Silicon Valley, Route 128, Carolina's Research Triangle and hi-tech Texas. Journal of information science 17(5), 273-280.

Janz, B. D. \& Prasarnphanich P. (2003). Understanding the antecedents of effective knowledge management, the importance of a knowledge centered culture. Decision sciences 34(2), 351-384.

Le Feuvre, N. \& Metso M. (2005). Disciplinary barriers between the social sciences and humanitiesnational report on France. Université de Toulouse-Le Mirail, mimeo.

Levine, A. (2006). Will universities maintain control of teacher education? Change, The Magazine of Higher Learning 38(4), 36-43.

Masland, A. T. (1985). Organizational culture in the study of higher education. The Review of Higher Education 8(2), 157-168.

McNay, I. (1995). From the collegial academy to corporate enterprise, the changing cultures of universities. The changing university 9, 105-115.

Mintzberg, H. (1983). Structure in fives, designing effective organizations, Englewood Cliffs, NJ, PrenticeHall.

Nonaka, I. \& Takeuchi H. (1995). The knowledge-creating company, How Japanese companies create the dynamics of innovation, Oxford university press.

Paul, J. J. (1990). Technical secondary education in Togo and Cameroon-research note. Economics of Education Review 9(4), 405-409.

Peralta, C. F., \& Saldanha, M. F. (2014). Knowledge-centered culture and knowledge sharing, the moderator role of trust propensity. Journal of Knowledge Management 18(3), 538-550.

Pfeffer, J., \& Sutton, R. I. (2000). The knowing-doing gap, How smart companies turn knowledge into action. Harvard business press.

Pineda, J. L., Zapata, L. E. \& Ramirez, J. (2010). Strengthening Knowledge Transfer between the University and Enterprise, A Conceptual Model for Collaboration. Cultural Implications of Knowledge Sharing, Management and Transfer, Identifying Competitive Advantage, IGI Global, 134-151.

Ponnuswamy, I., \& Manohar, H. L. (2016). Impact of learning organization culture on performance in higher education institutions. Studies in Higher Education, 41(1), 21-36.

Quinn, R. E. \& Rohrbaugh J. (1981). A competing values approach to organizational effectiveness. Public productivity review, 122-140.

Reichenfeld, L. (2011). The Barriers to Academic Engagement with Enterprise, A Social Scientist's Perspective. Innovation through Knowledge Transfer 2010. Vol (9), 163-176. Springer, Berlin, Heidelberg.

Rowley, J. (2000). Is higher education ready for knowledge management? International journal of educational management 14(7), 325-333.

Smart, J. C., \& St. John, E. P. (1996). Organizational culture and effectiveness in higher education, A test of the culture type and strong culture hypotheses. Educational evaluation and policy analysis, 18(3), 219-241.

Smith, H. A., \& McKeen, J. D. (2003). Knowledge management in organizations, the state of current practice. In Handbook on knowledge management (pp. 395-410). Springer, Berlin, Heidelberg.

Sporn, B. (1996). Managing university culture, an analysis of the relationship between institutional culture and management approaches. Higher education 32(1), 41-61.

Tănase, I. A. (2015). The importance of organizational culture based on culture transfer.". Management and Innovation for Competitive Advantage.

Taye, M., Sang, G., \& Muthanna, A. (2019). Organizational culture and its influence on the performance of higher education institutions: The case of a state university in Beijing. International Journal of Research, 8(2), 77-90.

Ternouth, P., Garner, C., Wood, L. \& Forbes, P. (2012). Key attributes for successful knowledge transfer partnerships. Council for Industry and Higher education. 
Tippins, M. J. (2003). Implementing knowledge management in academia, teaching the teachers. International journal of educational management 17(7), 339-345.

Tjeldvoll, A. (2002). The service university in the knowledge economy of Europe. European universities, Change and convergence, 85-109.

Uttley, J. (2019). Power Analysis, Sample Size, and Assessment of Statistical Assumptions-Improving the Evidential Value of Lighting Research. Leukos 15(2-3), 143-162.

Weber, Y. (1996). Corporate cultural fit and performance in mergers and acquisitions. Human relations 49(9), 1181-1202.

Wedgewood, M. (2006). Mainstreaming the third stream. Beyond mass higher education, Building on experience. Open University Press, Stony Stratford 134-157.

Weick, K. E. (1976). Educational organizations as loosely coupled systems. Administrative science quarterly, 1-19.

Wiig, K. M. (1993). Knowledge management foundations, thinking about thinking, how people and organizations create, represent, and use knowledge, Schema press Arlington, TX.

Wiig, K. M. (1997). Knowledge management, Where did it come from and where will it go? Expert systems with applications 13(1), 1-14.

Winter, R. (2009). Academic manager or managed academic? Academic identity schisms in higher education. Journal of higher education policy and management 31(2), 121-131.

Zamini, S., Zamini, S., \& Barzegary, L. (2011). The relationship between organizational culture and job burnout among the professors and employees in the University of Tabriz. Procedia-Social and Behavioral Sciences, 30, 1964-1968.

\section{Appendix-I}

\begin{tabular}{|c|c|}
\hline $\begin{array}{l}\text { Higher Education } \\
\text { Orientation: } \\
\text { Organizational C } \\
\end{array}$ & $\begin{array}{c}\text { Institution- 01 } \\
\text { Internal } \\
\text { ulture Type: Clan }\end{array}$ \\
\hline $\begin{array}{l}\text { Dominant } \\
\text { Characteristics }\end{array}$ & $\begin{array}{l}\text { The organization is very results-oriented. A major concern is with getting the job done. } \\
\text { People are very competitive and achievement-oriented. }\end{array}$ \\
\hline $\begin{array}{l}\text { Organizational } \\
\text { Leadership }\end{array}$ & $\begin{array}{l}\text { The leadership in the organization is generally considered to exemplify coordinating, } \\
\text { organizing, or smooth-running efficiency. }\end{array}$ \\
\hline $\begin{array}{l}\text { Management of } \\
\text { Employees }\end{array}$ & $\begin{array}{l}\text { The management style in the organization is characterized by teamwork, consensus, } \\
\text { and participation. }\end{array}$ \\
\hline $\begin{array}{l}\text { Organization } \\
\text { Glue }\end{array}$ & $\begin{array}{l}\text { The glue that holds the organization together is loyalty and mutual trust. Commitment } \\
\text { to this organization runs high. }\end{array}$ \\
\hline $\begin{array}{l}\text { Strategic } \\
\text { Emphases }\end{array}$ & $\begin{array}{l}\text { The organization emphasizes human development. High trust, openness, and } \\
\text { participation persist. }\end{array}$ \\
\hline $\begin{array}{l}\text { Criteria } \\
\text { Success }\end{array}$ & $\begin{array}{l}\text { Success in the organization is defines in terms of team work, concern for people, } \\
\text { development of human resource and commitment. }\end{array}$ \\
\hline \multicolumn{2}{|c|}{ Higher Education Institution- 02} \\
\hline \multicolumn{2}{|c|}{$\begin{array}{l}\text { Orientation: } \\
\text { Organizational Culture Type: }\end{array}$} \\
\hline $\begin{array}{l}\text { Dominant } \\
\text { Characteristics }\end{array}$ & $\begin{array}{l}\text { The organization is very results-oriented. A major concern is with getting the job } \\
\text { done. People are very competitive and achievement-oriented. }\end{array}$ \\
\hline $\begin{array}{l}\text { Organizational } \\
\text { Leadership }\end{array}$ & $\begin{array}{l}\text { The leadership in the organization is generally considered to exemplify } \\
\text { entrepreneurship, innovation, or risk taking. }\end{array}$ \\
\hline $\begin{array}{l}\text { Management } \mathrm{o} \\
\text { Employees }\end{array}$ & $\begin{array}{l}\text { The management style in the organization is characterized by teamwork, consensus, } \\
\text { and participation. }\end{array}$ \\
\hline Organization Glue & The glue that holds the organization together is commitment to innovation and \\
\hline
\end{tabular}




\begin{tabular}{|c|c|}
\hline & an emphasis on being on the cutting edge. \\
\hline $\begin{array}{l}\text { Strategic } \\
\text { Emphases }\end{array}$ & $\begin{array}{l}\text { The organization emphasizes permanence and stability. Efficiency, control and } \\
\text { smooth operations are important. }\end{array}$ \\
\hline Criteria of Success & $\begin{array}{l}\text { Success in the organization is defines in terms of team work, concern for people, } \\
\text { development of human resource and commitment. }\end{array}$ \\
\hline $\begin{array}{l}\text { Higher Education I } \\
\text { Orientation: } \\
\text { Organizational Cul }\end{array}$ & $\begin{array}{cccc}\text { nstitution- 05 } & & \\
\text { Internal } & \text { Focus } & \text { and } & \text { Stability } \\
\text { ture Type: Hierarchy } & & & \end{array}$ \\
\hline $\begin{array}{l}\text { Dominant } \\
\text { Characteristics }\end{array}$ & $\begin{array}{l}\text { The organization is a very personal place. It is like an extended family. People seem } \\
\text { to share a lot of themselves. }\end{array}$ \\
\hline $\begin{array}{l}\text { Organizational } \\
\text { Leadership }\end{array}$ & $\begin{array}{l}\text { The leadership in the organization is generally considered to exemplify } \\
\text { coordinating, organizing, or smooth-running efficiency. }\end{array}$ \\
\hline $\begin{array}{l}\text { Management } \\
\text { Employees }\end{array}$ & $\begin{array}{l}\text { The management style in the organization is characterized by security of } \\
\text { employment, conformity, predictability, and stability in relationships. }\end{array}$ \\
\hline Organization Glue & $\begin{array}{l}\text { The glue that holds the organization together is loyalty and mutual trust. } \\
\text { Commitment to this organization runs high. }\end{array}$ \\
\hline $\begin{array}{l}\text { Strategic } \\
\text { Emphases }\end{array}$ & $\begin{array}{l}\text { The organization emphasizes permanence and stability. Efficiency, control and } \\
\text { smooth operations are important. }\end{array}$ \\
\hline Criteria of Success & $\begin{array}{l}\text { Success in the organization is defined in terms efficiency, smooth and dependable } \\
\text { delivery of service }\end{array}$ \\
\hline \multicolumn{2}{|c|}{$\begin{array}{l}\text { Orientation: } \\
\text { Organizational Culture Type: Clan }\end{array}$} \\
\hline $\begin{array}{l}\text { Dominant } \\
\text { Characteristics }\end{array}$ & $\begin{array}{l}\text { The organization is a very controlled and structured place. Formal procedures } \\
\text { generally govern what people do. }\end{array}$ \\
\hline $\begin{array}{l}\text { Organizational } \\
\text { Leadership }\end{array}$ & $\begin{array}{l}\text { The leadership in the organization is generally considered to exemplify mentoring, } \\
\text { facilitating, or nurturing. }\end{array}$ \\
\hline $\begin{array}{l}\text { Management of } \\
\text { Employees }\end{array}$ & $\begin{array}{l}\text { The management style in the organization is characterized by teamwork, consensus, } \\
\text { and participation. }\end{array}$ \\
\hline Organization Glue & $\begin{array}{l}\text { The glue that holds the organization together is loyalty and mutual trust. } \\
\text { Commitment to this organization runs high. }\end{array}$ \\
\hline $\begin{array}{l}\text { Strategic } \\
\text { Emphases }\end{array}$ & $\begin{array}{l}\text { The organization emphasizes human development. High trust, openness, and } \\
\text { participation persist. }\end{array}$ \\
\hline Criteria of Success & $\begin{array}{l}\text { Success in the organization is defines in terms of team work, concern for people, } \\
\text { development of human resource and commitment. }\end{array}$ \\
\hline $\begin{array}{l}\text { Higher Education I } \\
\text { Orientation: } \\
\text { Organizational Cul }\end{array}$ & $\begin{array}{c}\text { Internal } \\
\text { ture Type: Clan }\end{array}$ \\
\hline $\begin{array}{l}\text { Dominant } \\
\text { Characteristics }\end{array}$ & $\begin{array}{l}\text { The organization is a very personal place. It is like an extended family. People } \\
\text { seem to share a lot of themselves. }\end{array}$ \\
\hline $\begin{array}{l}\text { Organizational } \\
\text { Leadership }\end{array}$ & $\begin{array}{l}\text { The leadership in the organization is generally considered to exemplify } \\
\text { coordinating, organizing, or smooth-running efficiency. }\end{array}$ \\
\hline $\begin{array}{l}\text { Management of } \\
\text { Employees }\end{array}$ & $\begin{array}{l}\text { The management style in the organization is characterized by teamwork, consensus, } \\
\text { and participation. }\end{array}$ \\
\hline Organization Glue & $\begin{array}{l}\text { The glue that holds the organization together is loyalty and mutual trust. } \\
\text { Commitment to this organization runs high. }\end{array}$ \\
\hline $\begin{array}{l}\text { Strategic } \\
\text { Emphases }\end{array}$ & $\begin{array}{l}\text { The organization emphasizes human development. High trust, openness, and } \\
\text { participation persist. }\end{array}$ \\
\hline Criteria of Success & $\begin{array}{l}\text { Success in the organization is defines in terms of team work, concern for people, } \\
\text { development of human resource and commitment. }\end{array}$ \\
\hline
\end{tabular}




\begin{tabular}{|c|c|}
\hline $\begin{array}{l}\text { Higher Education I } \\
\text { Orientation: } \\
\text { Organizational Cul }\end{array}$ & $\begin{array}{l}\text { nstitution- 10 } \\
\text { Internal } \\
\text { ture Type: Market }\end{array}$ \\
\hline $\begin{array}{l}\text { Dominant } \\
\text { Characteristics }\end{array}$ & $\begin{array}{l}\text { The organization is very results-oriented. A major concern is with getting the job } \\
\text { done. People are very competitive and achievement-oriented. }\end{array}$ \\
\hline Organizational & $\begin{array}{l}\text { The leadership in the organization is generally considered to exemplify } \\
\text { coordinating, organizing, or smooth-running efficiency. }\end{array}$ \\
\hline $\begin{array}{l}\text { Management } \\
\text { Employees }\end{array}$ & $\begin{array}{l}\text { The management style in the organization is characterized by teamwork, consensus, } \\
\text { and participation. }\end{array}$ \\
\hline Organization Glue & $\begin{array}{l}\text { The glue that holds the organization together is formal rules and policies. } \\
\text { Maintaining a smooth-running organization is important. }\end{array}$ \\
\hline $\begin{array}{l}\text { Strat } \\
\text { Emp }\end{array}$ & $\begin{array}{l}\text { The organization emphasizes human development. High trust, openness, and } \\
\text { participation persist. }\end{array}$ \\
\hline Criteria of Success & $\begin{array}{l}\text { Success in the organization is defined in terms of competitive performance that } \\
\text { outperforms market competition. }\end{array}$ \\
\hline \multicolumn{2}{|c|}{$\begin{array}{llll}\text { Higher Education Institution- 11 } & & \\
\text { Orientation: Internal } & \text { Focus } & \text { and } & \text { Flexible } \\
\text { Organizational Culture Type: Clan } & & \end{array}$} \\
\hline ics & $\begin{array}{l}\text { The organization is a very controlled and structured place. Formal proc } \\
\text { generally govern what people do. }\end{array}$ \\
\hline onal & $\begin{array}{l}\text { The leadership in the organization is generally considered to exemplify } \\
\text { coordinating, organizing, or smooth-running efficiency. }\end{array}$ \\
\hline ent of & $\begin{array}{l}\text { The management style in the organization is characterized by teamwork, consensus, } \\
\text { and participation. }\end{array}$ \\
\hline Organization Glue & $\begin{array}{l}\text { The glue that holds the organization together is formal rules and policies. } \\
\text { Maintaining a smooth-running organization is important. }\end{array}$ \\
\hline $\begin{array}{l}\mathrm{S} \\
\mathrm{E}\end{array}$ & $\begin{array}{l}\text { The organization emphasizes human development. High trust, openness, and } \\
\text { participation persist. }\end{array}$ \\
\hline Success & $\begin{array}{l}\text { Success in the organization is defined in terms of competitive performance that } \\
\text { outperforms market competition. }\end{array}$ \\
\hline \multicolumn{2}{|c|}{$\begin{array}{llll}\text { Higher Education Institution- 14 } & & \\
\text { Orientation: } & \text { Focus } & \text { and } & \text { Flexible }\end{array}$} \\
\hline & Ired place. Formal procedures \\
\hline al & $\begin{array}{l}\text { The leadership in the organization is generally considered to exemplify mentoring, } \\
\text { facilitating, or nurturing. }\end{array}$ \\
\hline $\begin{array}{l}\text { Management } \\
\text { Employees }\end{array}$ & $\begin{array}{l}\text { The management style in the organization is characterized by teamwork, consensus, } \\
\text { and participation. }\end{array}$ \\
\hline ion Glue & $\begin{array}{l}\text { The glue that holds the organization together is loyalty and mutual trust. } \\
\text { Commitment to this organization runs high. }\end{array}$ \\
\hline & $\begin{array}{l}\text { The organization emphasizes human development. High trust, openness, and } \\
\text { participation persist. }\end{array}$ \\
\hline iccess & $\begin{array}{l}\text { Success in the organization is defines in terms of team work, concern for people, } \\
\text { development of human resource and commitment. }\end{array}$ \\
\hline $\begin{array}{l}\text { Higher Educatiol } \\
\text { Orientation: } \\
\text { Organizational C }\end{array}$ & $\begin{array}{l}\text { Intution- 16 } \\
\text { e Type: Clan }\end{array}$ \\
\hline & The organization \\
\hline
\end{tabular}




\begin{tabular}{|c|c|}
\hline $\begin{array}{l}\text { Organizational } \\
\text { Leadership }\end{array}$ & $\begin{array}{l}\text { The leadership in the organization is generally considered to exemplify mentoring, } \\
\text { facilitating, or nurturing. }\end{array}$ \\
\hline $\begin{array}{l}\text { Management of } \\
\text { Employees }\end{array}$ & $\begin{array}{l}\text { The management style in the organization is characterized by teamwork, consensus, } \\
\text { and participation. }\end{array}$ \\
\hline Organization Glue & $\begin{array}{l}\text { The glue that holds the organization together is loyalty and mutual trust. } \\
\text { Commitment to this organization runs high. }\end{array}$ \\
\hline $\begin{array}{l}\text { Strategic } \\
\text { Emphases }\end{array}$ & $\begin{array}{l}\text { The organization emphasizes permanence and stability. Efficiency, control and } \\
\text { smooth operations are important. }\end{array}$ \\
\hline Criteria of Success & $\begin{array}{l}\text { Success in the organization is defines in terms of team work, concern for people, } \\
\text { development of human resource and commitment. }\end{array}$ \\
\hline \multicolumn{2}{|c|}{$\begin{array}{lr}\text { Orientation: } & \text { Internal } \\
\text { Organizational Culture Type: Clan }\end{array}$} \\
\hline $\begin{array}{l}\text { Dominant } \\
\text { Characteristics }\end{array}$ & $\begin{array}{l}\text { The organization is a very personal place. It is like an extended family. People seem } \\
\text { to share a lot of themselves. }\end{array}$ \\
\hline $\begin{array}{l}\text { Organizational } \\
\text { Leadership }\end{array}$ & $\begin{array}{l}\text { The leadership in the organization is generally considered to exemplify mentoring, } \\
\text { facilitating, or nurturing }\end{array}$ \\
\hline $\begin{array}{l}\text { Management of } \\
\text { Employees }\end{array}$ & $\begin{array}{l}\text { The management style in the organization is characterized by teamwork, consensus, } \\
\text { and participation. }\end{array}$ \\
\hline Organization Glue & $\begin{array}{l}\text { The glue that holds the organization together is loyalty and mutual trust. } \\
\text { Commitment to this organization runs high. }\end{array}$ \\
\hline $\begin{array}{l}\text { Strategic } \\
\text { Emphases }\end{array}$ & $\begin{array}{l}\text { The organization emphasizes permanence and stability. Efficiency, control and } \\
\text { smooth operations are important. }\end{array}$ \\
\hline Criteria of Success & $\begin{array}{l}\text { Success in the organization is defines in terms of team work, concern for people, } \\
\text { development of human resource and commitment. }\end{array}$ \\
\hline
\end{tabular}

